\title{
The Integration of Different Curriculum Ideologies in a School Science Subject
}

\author{
Lindelani Mnguni
}

Citation: Mnguni, L. The Integration of Different Curriculum Ideologies in a School Science Subject. Educ. Sci. 2021, 11, 551. https://doi.org/ 10.3390/educsci11090551

Academic Editor: Keith Morrison

Received: 28 August 2021

Accepted: 13 September 2021

Published: 16 September 2021

Publisher's Note: MDPI stays neutral with regard to jurisdictional claims in published maps and institutional affiliations.

Copyright: (C) 2021 by the author. Licensee MDPI, Basel, Switzerland. This article is an open access article distributed under the terms and conditions of the Creative Commons Attribution (CC BY) license (https:// creativecommons.org/licenses/by/ $4.0 /)$.
Department of Science \& Technology Education, College of Education, University of South Africa, Pretoria 0181, South Africa; lindelani.mnguni@wits.ac.za

\begin{abstract}
School science subjects may be informed by curriculum ideologies such as disciplinecentered, service-centered, student-centered, or citizen-centered ideologies. The distinct characteristics of each ideology complicate the extent to which science subjects could integrate different curriculum ideologies. Consequently, the present research explored how different curriculum ideologies are reflected in a school science subject. Natural Sciences was used as a case study that followed a mixed-methods approach. Inductive content analysis was performed on the curriculum document to determine its foregrounding curriculum ideologies using a validated open-ended instrument. Findings indicate that Natural Sciences integrates four curriculum ideologies concurrently. These are the student-centered ideology, service-centered ideology, discipline-centered ideology, and citizenship-centered ideology. However, while attempting to adopt multi-curriculum ideologies, the subject could not ensure equal representation of these ideologies. For example, citizenship-centered ideology received the least representation even though it is the ideology most related to the imperatives of social empowerment. It is concluded that the integration of different ideologies may lead to teaching difficulties where teachers find it challenging to adapt teaching methods that satisfy all four curriculum ideologies. Additionally, students in different schools may be taught according to different curriculum ideology principles, leading to inconsistencies in attained learning outcomes.
\end{abstract}

Keywords: curriculum ideologies; content analysis; natural sciences; school science

\section{Introduction}

Over the past century, the knowledge explosion, particularly in science, has meant that curriculum designers have a difficult decision to make regarding content knowledge to include in school curricula [1]. Fraser [2] suggested that in primary education, curriculum designers should include knowledge that will orientate students towards a wide variety of careers but should avoid premature over-emphasis of any one specialization, as this could limit and narrow student development. However, Fraser [2] suggested that the content selected should be applicable, valid, significant, learnable, durable, and variable. To achieve this, scholars have suggested that school subjects should follow an integrated curriculum model. Humphreys et al. [3] (p. 11) defined an integrated curriculum as "one in which children broadly explore knowledge in various subjects related to certain aspects of their environment". In such a curriculum, students are exposed to content related to "humanities, communication arts, natural sciences, mathematics, social studies, music, and art" [4]. Shoemaker [5] (p. 5) also supported this view by suggesting that in an integrated curriculum, learning "is organised in such a way that it cuts across subject-matter lines, bringing together various aspects of the curriculum into a meaningful association to focus upon broad areas of study. It views learning and teaching holistically and reflects the real world, which is interactive". An integrated curriculum model was adopted in South Africa in developing the compulsory school science subject Natural Sciences for Senior Phase (Grade 7 to 9). Students are exposed to scientific content knowledge related to biology, chemistry, physics, geography, and environmental sciences in this subject. Several 
researchers have explored the underlying socio-political framework that informs this curriculum [6,7]. Chisholm [7] suggested that in developing the South African curriculum, curriculum designers contended between the ideas of the curriculum as a policy and curriculum as knowledge. In the curriculum as policy, the underlying principle is that the curriculum must create common ground for diverse groups that seek to ensure that their "interests, values, histories, and politics" are reflected in the curriculum [7] (p. 194). From a knowledge perspective, the curriculum adopts a student-centered, outcomes-based constructivist philosophy [7]. Badat and Sayed [6] argued that the South African curriculum seeks to introduce, support, and promote citizenship education. In this context, the revised curriculum ensures that students have relevant skills and knowledge to think critically and participate in society's reconstruction and empowerment $[8,9]$.

\subsection{Problem of Research}

The problem statement addressed in the present research was the apparent challenge of satisfying the socio-economic, political, and scientific needs of education in the 21st century. In addition to increased content knowledge, school science curricula, including the South African Natural Sciences curriculum, are faced with the need to facilitate the acquisition of introductory scientific knowledge among students. They also have to contend with socio-political demands and, in most cases, reflect liberal and democratic content and pedagogy [10,11]. Scholars such as Hoeg and Bencze [12] have argued that a curriculum should enhance students' socio-economic and scientific competitiveness and their countries'. It is suggested that curricula must also seek to translate new ideas into educational practices [13], standardize content and learning outcomes [14], renew educational content and experiences, as well as introduce student-centered curricula, content, and pedagogies [15].

Therefore, the socio-scientific and political demands of curriculum reform mean science curriculum designers have difficulty satisfying the educational demands of curriculum theory with those of society. Given this, one wonders about the ideal curriculum ideology that could satisfy education's socio-economic, political, and scientific needs. A curriculum ideology can be defined as the combined conception of the "purpose of education, the characterisation of the student and the teacher and their respective roles during teaching and learning as well as the nature, function, and purpose of knowledge, instructional process, and assessment" [16] (p. 3). Therefore, a curriculum ideology informs all teaching and learning processes and could determine the extent to which curriculum reform could be successful. Using South African Natural Sciences as a case study, the present research sought to explore the curriculum ideology underlying a science subject that adopts an integrated curriculum model.

\subsection{Purpose and Research Question of the Research}

Given the above research problem, the purpose of the present research was to determine how a school science subject integrates different curriculum ideologies. This aimed to determine the underlying theoretical nature of Natural Sciences to determine the extent to which a science subject could effectively integrate different curriculum ideologies. The current research question asked: how are different curriculum ideologies integrated into a school science subject?

\subsection{The Theoretical Framework of the Research}

Over the years, there have been alternative views regarding the nature of science curricula adopted by schools. For example, in the United States in the 1960s, there was skepticism on the potential of discipline-based science curricula to address social problems $[17,18])$. This led to increasing support for an integrated curriculum organized around socio-economic, political, and scientific challenges that faced societies [18]. This trend grew to other parts of the world, including Asia, where the integrated curriculum was viewed as 
a means of expanding students' international awareness through problem-based learning rather than content-based learning [18].

However, an integrated science curriculum's success depends on the teacher's conception, acceptance, and ability to effectively interpret social contexts and integrate these into the classroom practice $[19,20]$. Therefore, inadequate teacher preparation is a significant factor in the successful implementation of an integrated curriculum. Furthermore, an integrated curriculum poses challenges regarding accountability and standardized testing [21]. As a result, most educational authorities have favored the discipline-based science curriculum [18].

Perennialism and essentialism have been most influential in shaping discipline-based curricula in science education [22]. This is because perennialists view knowledge as permanent and classifiable into distinct science subjects such as biology and physics [23]. They view teachers as experts who guide students toward a deeper understanding of universal scientific truths within specific subject areas. Similarly, essentialists view knowledge as tentative but durable and applicable to contemporary issues [24]. Teachers in this regard are tasked with teaching pre-existing knowledge within emerging contexts. Curricula informed by perennialists and essentialist views rely on the narrow measurement of student achievement through testing to prepare students for specific future roles in society within specialized disciplines [18]. An opposing philosophy is that offered by progressivism and reconstructivism. Progressives and reconstructionist view the school as a microcosm of society where students must develop inquiry, collaboration, and self-discipline to democratically solve issues in society as change agents [24].

Given the above philosophical perspectives, one wonders whether it is possible to have a science curriculum integrating various philosophies. This question can be also be understood from a curriculum ideology perspective. Perennialism, essentialism, progressivism, and reconstructionism are four widely accepted curriculum ideologies with unique characteristics within the curriculum's six components. These components are the (i) purpose of the subject, (ii) the nature of knowledge, (iii) the instructional process (including teaching and learning), (iv) the role of the teachers, (v) the role of the students, as well as (vi) the assessment [25].

Similar to perennialism, the discipline-centered ideology fosters the transmission of discipline-specific scientific knowledge from discipline experts to students. As such, students are taught the epistemological and the ontological principles of the discipline to believe that such a pedagogical approach will preserve the autonomy of academic disciplines and the associated knowledge [26-28]. Similarly, the service-centered ideology borrows from essentialism by teaching what is regarded as enduring essential knowledge and skills which students will utilize when rendering specific discipline-orientated services [26]. Therefore, teachers are tasked with identifying societal problems that require scientific knowledge and skills and then developing learning programs to transmit knowledge and skills, which students need to provide essential services to society. As the name suggests, the student-centered ideology places the student at the center of teaching and learning. Here, the curriculum's primary function is to support the development of cognitive, affective, and psychomotor skills among students. In this ideology, teaching is viewed as a nurturing process where the construction of scientific knowledge and development of scientific skills is facilitated by teachers [28]. The citizenship-centered ideology, on the other hand, is reconstructionist in nature. Fundamentally, it assumes that society can be transformed through a reconstructionist form of education [26]. Teachers are tasked with teaching socio-scientific knowledge and skills [28] that can transform social norms and values of students and enhance civilization [29-31]. Emerging knowledge is used to transform students' beliefs, attitudes, values, and ultimately behaviors with a view that this transformation will, in turn, lead to a reconstruction of broader social norms [26]. Given each of the above curriculum ideologies' distinct nature, the extent to which a science curriculum could adopt all four ideologies informed by the various philosophies remains to be investigated. 


\section{Research Methodology}

The realism research paradigm was adopted as the research paradigm that guided the current research methods. This is because realism allows for integrating both qualitative and quantitative research approaches [32]. Regarding quantitative methods, descriptive statistical analyses were performed on the data, while document and thematic analyses were performed for qualitative data analysis. By blending these two research approaches, researchers can enhance the validity and credibility of their findings. As a result, the researchers followed the explanatory mixed-method approach for data collection and analysis. Therefore, the current researcher followed an exploratory mixed-method approach, with content analysis adopted.

Content analysis was preferred as it "provides a systematic and objective means to make valid inferences from verbal, visual, or written data in order to describe and quantify phenomena" [33] (p. 314). The significant advantage of content analysis is that unlike document analysis, which is a form of qualitative research [34,35], content analysis "is more than a counting game; it is concerned with meaning, intentions, consequences and context" [33] (p. 314). It also allows the researcher to make inferences concerning the context from which data were produced. Given the realism research paradigm and the exploratory mixed-method approach adopted in this current research, content analysis was identified as the most suitable analytical method.

Data were collected and analyzed over two years between 2017-2018. The specific details, such as sampling and data analysis, are presented below.

\subsection{Data Sources}

Because the research method was content analysis, the source of data in the present research was the Curriculum and Assessment Policy Statement (CAPS) for Natural Sciences Grade 7 to 9 [36], hereafter referred to as the CAPS document. Natural Sciences is a compulsory integrated school science subject taught in Grades 7 to 9 in South Africa. It teaches content related to biology, chemistry, physics, geography, and environmental sciences. The CAPS document is mandatory in all government schools in South Africa, and it provides specific content, learning outcomes, and assessments that must be implemented in schools. The CAPS document also provides guidelines for instructional processes, including the roles of teachers and students. Therefore, the CAPS document for Natural Sciences was the document on which content analysis was performed in the present research.

\subsection{Data Analysis}

The CAPS document was analyzed inductively by the researchers using a previously validated standardized content analysis instrument (VSDAI) [11] (Table 1). The VSDAI is a short open-ended questionnaire that consists of six items. These items were adopted from Schiro's [28] curriculum analysis instrument for identifying a curriculum ideology. In its development, the researchers adopted the six items from Schiro's [28] standard inventory. The instrument was previously used to determine school Biology curriculum ideology [25] and Physical Sciences and Mathematics [16]. Based on its successful use in these studies, the VSDAI was deemed usable in the present research.

Table 1. The standardized content analysis instrument (VSDAI) was used for content analysis (adapted from Mnguni [11]).

Purpose of Analysis

Open-Ended Questions Were Used to Analyze the Curriculum Documents.

(a) What is the aim of the curriculum?

(b) What kind of knowledge is prescribed in the curriculum?

(c) How is learning supposed to take place?

To determine the curriculum ideologies adopted in the Natural Sciences curriculum. process?

(e) What is the role of teachers during instruction?

(f) What is the purpose of the assessment? 
However, to further ensure validity, the instrument was validated through a panel of 7 science education research experts. The purpose here was to enhance the face, content, and criterion-related validity of the instrument. A content validity index of $82 \%$ was obtained from these experts who validated the instruments, which suggested that the instrument was fit for purpose. Having satisfied instrument validity, the VSDAI instrument was used to analyze the curriculum document. This analysis was performed by two researchers jointly. The panel of 7 science education research experts was then tasked with determining consistency in using the instrument by the researchers in line with what the instrument was designed for. The panel concluded that the instrument was used accordingly.

Therefore, during content analysis, the two researchers analyzed the CAPS document and formulated responses to the VSDAI items inductively using verbatim and narrated extracts from the CAPS documents. These extracts were identified by searching for a specific keyword in the CAPS document. The researchers generated the keywords based on Schiro's [28] characterization of the different curriculum ideologies. For example, in searching for the aim of the subject, the researchers asked, "what is the aim of Natural Sciences?" According to Schiro [28], the aim could be "understanding content", "doing action with content", "actualising oneself", or "interpreting and reconstructing society" using knowledge. The keywords used in AtlasTi, therefore, included Aim(s), Goal(s), Intention(s), Objective(s), Outcome(s), and Purpose(s). In this instance, the researchers used AtlasTi to search for these keywords. A manual search of these keywords was also performed for validity purposes. It included a study of the text to identify any other contexts in which the purpose of the subject may have been expressed. The emerging verbatim extracts were organized as responses to the VSDAI items. These were then classified and interpreted qualitatively and quantitatively to make inferences regarding the curriculum ideology of Natural Sciences as reflected in the CAPS documents.

\section{Results}

The analysis of the CAPS Natural Sciences revealed that the document is divided into four sections. The first section, which is $4 \%$ of the document (5 out of 93 pages), introduces the entire schooling curriculum, including other school subjects, the general aims of the South African Curriculum, and time allocation across the different phases. These phases include the Foundation Phase (Grades 1 to 3), Intermediate Phase (Grades 4 to 6), the Senior Phase (Grades 7 to 9), and the FET Phase (Grade 10 to 12). Natural Sciences is compulsory for all students in the Senior Phase, where it is allocated $11 \%$ of teaching time weekly. Two language subjects and Mathematics receive the most time. The second section of the CAPS document [36] occupies $10 \%$ of the document and provides a detailed overview of the Natural Sciences subject. It discusses indigenous knowledge systems, teaching, organization of the subject, as well as teaching time. Specific aims, process skills, and resources required for teaching Natural Sciences are also listed together with a summary of the concepts and content learned in Natural Sciences. Section three provides a comprehensive list of topics organized into knowledge strands that are taught in the subject. It also provides a detailed breakdown of time allocated to each topic and strand in order the topics must be taught. It also provides suggested learning activities, including investigations, practical work, and demonstrations that teachers could adopt. In this instance, recommended teaching equipment and resources are also listed. This section occupies $73 \%$ of the CAPS document in page volume. The last section provides a detailed assessment guideline, including informal and formal assessments. It prescribes assessment requirements, recording and reporting procedures, as well as moderation strategies. This section occupies $9 \%$ of the CAPS document in page volume.

The CAPS document has 93 pages, in which 402 units of evidence in the form of paragraphs spanning at least one sentence were identified as reflecting at least one curriculum ideology. Of these units, $31 \%(n=124)$ reflected the student-centered ideology, $30 \%(n=121)$ reflected the service-centered ideology, $24 \%(n=94)$ reflected the discipline- 
centered, and $15 \%(n=60)$ reflected the citizenship-centered ideology. Data also showed that each curriculum ideology is reflected in the six investigated components (see Table 2). For example, with regards to the purpose of the subject, the curriculum indicates that the purpose of Natural Sciences is that "students should have a grasp of scientific, technological and environmental knowledge and be able to apply it in new contexts" (Table 2, [36] p. 10). This "grasping" of seemingly already existing "scientific, technological, and environmental knowledge" is typically discipline-centered in nature, where students are expected to "understand reality".

Table 2. Curriculum ideologies are generally reflected in the curriculum (adapted from the Department of Basic Education [36].

\begin{tabular}{|c|c|c|c|c|}
\hline Theme & $\begin{array}{l}\text { Guiding } \\
\text { Question }\end{array}$ & Example of Evidence & $\begin{array}{l}\text { Source (Page } \\
\text { Number in } \\
\text { CAPS } \\
\text { Document) }\end{array}$ & $\begin{array}{l}\text { Relevant } \\
\text { Curriculum } \\
\text { Ideology }\end{array}$ \\
\hline \multirow{4}{*}{$\begin{array}{l}\text { Purpose of the } \\
\text { subject }\end{array}$} & \multirow{4}{*}{$\begin{array}{l}\text { What is the } \\
\text { purpose of the } \\
\text { (sub- } \\
\text { ject/curriculum)? }\end{array}$} & $\begin{array}{l}\text { "Students should have a grasp of scientific, } \\
\text { technological and environmental knowledge } \\
\text { and be able to apply it in new contexts." }\end{array}$ & 10 & $\begin{array}{l}\text { Discipline- } \\
\text { cantered } \\
\text { ideology }\end{array}$ \\
\hline & & $\begin{array}{l}\text { "Facilitating the transition of students from } \\
\text { educational institutions to the workplace; and } \\
\text { providing employers with a sufficient profile } \\
\text { of a student's competencies." }\end{array}$ & 4 & $\begin{array}{c}\text { Service-centered } \\
\text { ideology }\end{array}$ \\
\hline & & $\begin{array}{l}\text { "This curriculum aims to ensure that children } \\
\text { acquire and apply knowledge and skills in } \\
\text { ways that are meaningful to their own lives." }\end{array}$ & 4 & $\begin{array}{c}\text { Student-centered } \\
\text { ideology }\end{array}$ \\
\hline & & $\begin{array}{l}\text { "The curriculum promotes knowledge in local } \\
\text { contexts while being sensitive to global } \\
\text { imperatives." }\end{array}$ & 4 & $\begin{array}{l}\text { Citizenship- } \\
\text { centered } \\
\text { ideology }\end{array}$ \\
\hline \multirow{4}{*}{$\begin{array}{c}\text { Content } \\
\text { knowledge }\end{array}$} & \multirow{4}{*}{$\begin{array}{l}\text { What is the nature } \\
\text { and purpose of } \\
\text { knowledge } \\
\text { prescribed in the } \\
\text { curriculum? }\end{array}$} & $\begin{array}{l}\text { "Indigenous knowledge includes knowledge } \\
\text { about agriculture and food production, } \\
\text { pastoral practices and animal production, } \\
\text { forestry, plant classification, medicinal plants, } \\
\text { biodiversity management, food preservation, } \\
\text { soil and water management, iron smelting, } \\
\text { brewing, and making dwellings, and } \\
\text { understanding astronomy." }\end{array}$ & 8 & $\begin{array}{c}\text { Service-centered } \\
\text { ideology }\end{array}$ \\
\hline & & $\begin{array}{l}\text { "Science, as we know it today, has roots in } \\
\text { African, Arabic, Asian, European and } \\
\text { American cultures. It has been shaped by the } \\
\text { search to understand the natural world } \\
\text { through observation, testing and proving of } \\
\text { ideas, and has evolved to become part of the } \\
\text { cultural heritage of all nations." }\end{array}$ & 8 & $\begin{array}{l}\text { Citizenship- } \\
\text { centered } \\
\text { ideology }\end{array}$ \\
\hline & & $\begin{array}{l}\text { "Science is a discipline that sustains } \\
\text { enjoyment and curiosity about the world and } \\
\text { natural phenomena." }\end{array}$ & 8 & $\begin{array}{c}\text { Student-centered } \\
\text { ideology }\end{array}$ \\
\hline & & $\begin{array}{l}\text { "The science knowledge we teach at school is } \\
\text { not in doubt, most of it has been tested and } \\
\text { known since the } 1800 \mathrm{s."}\end{array}$ & 8 & $\begin{array}{l}\text { Discipline- } \\
\text { centered } \\
\text { ideology }\end{array}$ \\
\hline
\end{tabular}


Table 2. Cont.

\begin{tabular}{|c|c|c|c|c|}
\hline Theme & $\begin{array}{l}\text { Guiding } \\
\text { Question }\end{array}$ & Example of Evidence & $\begin{array}{l}\text { Source (Page } \\
\text { Number in } \\
\text { CAPS } \\
\text { Document) }\end{array}$ & $\begin{array}{l}\text { Relevant } \\
\text { Curriculum } \\
\text { Ideology }\end{array}$ \\
\hline \multirow{4}{*}{$\begin{array}{l}\text { Instructional } \\
\text { process }\end{array}$} & \multirow{4}{*}{$\begin{array}{l}\text { How is learning } \\
\text { supposed to take } \\
\text { place? }\end{array}$} & $\begin{array}{l}\text { "Active and critical learning: encouraging an } \\
\text { active and critical approach to learning, rather } \\
\text { than rote learning." }\end{array}$ & 4 & $\begin{array}{l}\text { Student-centered } \\
\text { ideology }\end{array}$ \\
\hline & & \multirow{2}{*}{$\begin{array}{l}\text { "The teaching and learning of Natural } \\
\text { Sciences involves the development of a range } \\
\text { of process skills that may be used in everyday } \\
\text { life, in the community, and in the workplace." }\end{array}$} & \multirow[t]{2}{*}{10} & $\begin{array}{l}\text { Citizenship- } \\
\text { centered } \\
\text { ideology }\end{array}$ \\
\hline & & & & $\begin{array}{l}\text { Service-centered } \\
\text { ideology }\end{array}$ \\
\hline & & $\begin{array}{l}\text { "Every student should have access to } \\
\text { sufficient workspace and equipment to carry } \\
\text { out investigations." }\end{array}$ & 12 & $\begin{array}{l}\text { Discipline- } \\
\text { centered } \\
\text { ideology }\end{array}$ \\
\hline \multirow{4}{*}{ The student } & \multirow{4}{*}{$\begin{array}{l}\text { What are the } \\
\text { nature and the } \\
\text { role of students in } \\
\text { the learning } \\
\text { process? }\end{array}$} & $\begin{array}{l}\text { "The time allocated per topic is a guideline } \\
\text { and should be applied flexibly according to } \\
\text { circumstances in the classroom and to } \\
\text { accommodate the interests of the students." }\end{array}$ & 9 & $\begin{array}{l}\text { Student-centered } \\
\text { ideology }\end{array}$ \\
\hline & & $\begin{array}{l}\text { "Students need to make with related topics to } \\
\text { help them achieve a thorough understanding } \\
\text { of the nature of and the connectedness in } \\
\text { Natural Sciences." }\end{array}$ & 9 & $\begin{array}{l}\text { Discipline- } \\
\text { centered } \\
\text { ideology }\end{array}$ \\
\hline & & $\begin{array}{l}\text { "Students are required to read and write } \\
\text { particular genres of texts (including } \\
\text { instructions, reports, and explanations) } \\
\text { during Natural Sciences lessons." }\end{array}$ & 12 & $\begin{array}{l}\text { Service-centered } \\
\text { ideology }\end{array}$ \\
\hline & & $\begin{array}{l}\text { "Writing allows students to construct and } \\
\text { communicate thoughts and ideas coherently." }\end{array}$ & 12 & $\begin{array}{l}\text { Citizenship- } \\
\text { centered } \\
\text { ideology }\end{array}$ \\
\hline \multirow{4}{*}{ The teacher } & \multirow{4}{*}{$\begin{array}{l}\text { What is the role of } \\
\text { teachers during } \\
\text { instruction? }\end{array}$} & $\begin{array}{l}\text { "Teachers should ensure that a system is in } \\
\text { place for recovering textbooks at the end of } \\
\text { every year." }\end{array}$ & 12 & $\begin{array}{l}\text { Service-centered } \\
\text { ideology }\end{array}$ \\
\hline & & $\begin{array}{l}\text { "In instances where there is no alternative, it } \\
\text { is more effective for teachers to demonstrate } \\
\text { an investigation than not to do investigations } \\
\text { due to a lack of equipment." }\end{array}$ & 12 & $\begin{array}{l}\text { Discipline- } \\
\text { centered } \\
\text { ideology }\end{array}$ \\
\hline & & $\begin{array}{l}\text { "Teachers should remember that it is more } \\
\text { important for students to have the experience } \\
\text { of carrying out a variety of investigations than } \\
\text { to depend on the availability of equipment." }\end{array}$ & 12 & $\begin{array}{l}\text { Student-centered } \\
\text { ideology }\end{array}$ \\
\hline & & $\begin{array}{l}\text { "Teachers have the freedom to expand } \\
\text { concepts and to design and organise learning } \\
\text { experiences according to their own local } \\
\text { circumstances." }\end{array}$ & 16 & $\begin{array}{l}\text { Citizenship- } \\
\text { centered } \\
\text { ideology }\end{array}$ \\
\hline
\end{tabular}


Table 2. Cont.

\begin{tabular}{|c|c|c|c|c|}
\hline Theme & $\begin{array}{l}\text { Guiding } \\
\text { Question }\end{array}$ & Example of Evidence & $\begin{array}{l}\text { Source (Page } \\
\text { Number in } \\
\text { CAPS } \\
\text { Document) }\end{array}$ & $\begin{array}{l}\text { Relevant } \\
\text { Curriculum } \\
\text { Ideology }\end{array}$ \\
\hline \multirow{4}{*}{ Assessment } & \multirow{4}{*}{$\begin{array}{l}\text { What is the } \\
\text { purpose of the } \\
\text { assessment? }\end{array}$} & $\begin{array}{l}\text { "In any formal assessment, students should } \\
\text { be made aware of what will be assessed and } \\
\text { how that will be assessed." }\end{array}$ & 87 & $\begin{array}{c}\text { Student-centered } \\
\text { ideology }\end{array}$ \\
\hline & & $\begin{array}{l}\text { "The teacher observes the student } \\
\text { demonstrate specific practical skills ... } \\
\text { Practical tasks can be very useful for } \\
\text { assessing how students draw on knowledge } \\
\text { and values to carry out practical skills } \\
\text { (manual and/or behavioral, e.g., safety and } \\
\text { handling of equipment)." }\end{array}$ & 88 & $\begin{array}{c}\text { Service-centered } \\
\text { ideology }\end{array}$ \\
\hline & & $\begin{array}{l}\text { "Assessment should be mapped out against } \\
\text { the content (concepts and skills) and specific } \\
\text { aims for Natural Sciences." }\end{array}$ & 85 & $\begin{array}{l}\text { Discipline- } \\
\text { centered } \\
\text { ideology }\end{array}$ \\
\hline & & $\begin{array}{l}\text { "Assessment is a continuous and planned } \\
\text { process of identifying, gathering, interpreting } \\
\text { and diagnosing, information about the } \\
\text { performance of students." }\end{array}$ & 85 & $\begin{array}{l}\text { Citizenship- } \\
\text { centered } \\
\text { ideology }\end{array}$ \\
\hline
\end{tabular}

Similarly, as shown in Table 2, Natural Sciences also aims to facilitate "the transition of students from educational institutions to the workplace; and providing employers with a sufficient profile of a student's competences" [36] (p. 4). This preparation of students for specific roles in society is typical in service-centered ideology. Using this reasoning, therefore, the research revealed that all four curriculum ideologies are reflected in the Natural Sciences curriculum, albeit to varying extents.

The discipline-centered ideology was found to be the most dominant ideology reflected in the purpose of Natural Sciences and the nature and purpose of knowledge (see Figure 1). The student-centered ideology was most reflected in the instructional process and the roles of the teachers and students. The results also show that the citizenship-centered ideology was least reflected in all six curriculum components that were explored. However, the researcher also observed that conflicting perspectives emerge as a consequence of the adoption of multiple ideologies in some instances. For example, as part of the studentcentered ideology, the curriculum states that "students can gain skills in an environment that taps into their curiosity about the world, and that supports creativity" [36] (p. 19). This is conflicting in that while students are expected to be creative, such creativity may be limited by the management and limited resources. In these instances, teachers may revert to discipline-centered and service-centered ideologies where they rely on "practical demonstrations" [36] (p. 86) that do not afford students the hands-on experience envisaged in the student-centered ideology. This observation suggests that other factors, such as a lack of resources, may cause the adoption of opposing ideologies. 

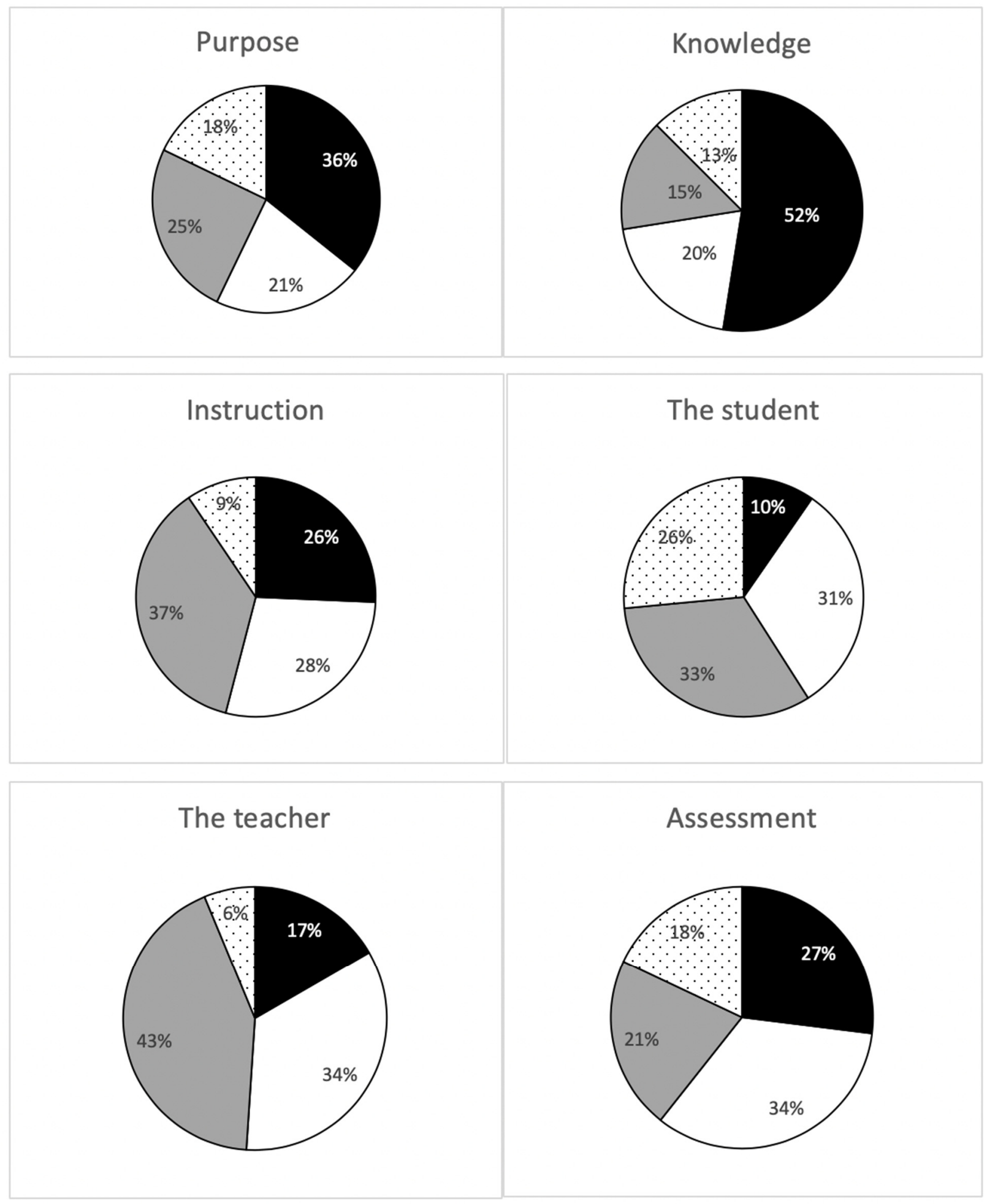

Figure 1. Distribution of the different curriculum ideologies in the CAPS document. Black is the discipline-centered ideology; white is the service-centered ideology; gray is the student-centered ideology; dotted is the citizenship-centered ideology.

Representation of the different ideologies was also reflected in the content knowledge and instructional methods recommended for Natural Sciences (e.g., Table 3). In this instance, it was found that each topic has been allocated a specific amount of time in which it must be taught. 
Table 3. Examples of topics in the CAPS document reflect different curriculum ideologies (Department of Basic Education, [36]).

\begin{tabular}{|c|c|c|c|c|c|}
\hline Topic & Recommended Activity & $\begin{array}{l}\text { Recommended } \\
\text { Resources }\end{array}$ & $\begin{array}{c}\text { Source (Page } \\
\text { Number in CAPS } \\
\text { Document }\end{array}$ & Grade & Classification \\
\hline Compounds & $\begin{array}{l}\text { Memorizing the name and the } \\
\text { symbol of each of the first } 20 \\
\text { Elements on the Periodic Table, as } \\
\text { well as iron (Fe), copper }(\mathrm{Cu}) \text {, zinc } \\
\text { ( } \mathrm{Zn}) \text { (students need not memorize } \\
\text { the atomic number of each } \\
\text { element) }\end{array}$ & $\begin{array}{l}\text { Periodic Table of } \\
\text { Elements }\end{array}$ & 63 & 9 & $\begin{array}{l}\text { Discipline- } \\
\text { centered } \\
\text { ideology }\end{array}$ \\
\hline $\begin{array}{l}\text { Chemical } \\
\text { reactions }\end{array}$ & $\begin{array}{l}\text { Discussing/reading about careers } \\
\text { in inorganic and organic } \\
\text { chemistry, mining, engineering, } \\
\text { materials development, and in the } \\
\text { biofuels industry (not for } \\
\text { assessment purposes) }\end{array}$ & None listed & 45 & 8 & $\begin{array}{l}\text { Service- } \\
\text { centered } \\
\text { ideology }\end{array}$ \\
\hline $\begin{array}{l}\text { The Solar } \\
\text { System }\end{array}$ & $\begin{array}{l}\text { Constructing a model of the Solar } \\
\text { System showing relative } \\
\text { distances of the planets from the } \\
\text { Earth and relative sizes of planets } \\
\text { Presenting a fact sheet about any } \\
\text { object found in our Solar System }\end{array}$ & $\begin{array}{l}\text { Video clips from } \\
\text { the internet }\end{array}$ & 53 & 8 & $\begin{array}{l}\text { Student- } \\
\text { centered } \\
\text { ideology }\end{array}$ \\
\hline Biodiversity & $\begin{array}{l}\text { Grouping a selection of everyday } \\
\text { objects according to observable } \\
\text { features, for example, shape, } \\
\text { color, size, and use }\end{array}$ & $\begin{array}{l}\text { Selection of } \\
\text { pictures, } \\
\text { photographs, or } \\
\text { drawings of } \\
\text { vertebrates and } \\
\text { invertebrates } \\
\text { Magnifying lenses, } \\
\text { live or preserved } \\
\text { specimens }\end{array}$ & 17 & 7 & $\begin{array}{l}\text { Citizenship- } \\
\text { centered } \\
\text { ideology }\end{array}$ \\
\hline
\end{tabular}

Under each topic, the CAPS document also specifies the "content \& concept" that must be taught together with suggested activities, including investigations, practical work, and demonstration. For example, in Grade 9, under the topic "compounds", students are taught that "each element on the Periodic Table (in its own block) has an atomic number (smaller number), mass number (larger number), name and symbol" [36] (p. 63). A suggested activity in this regard is "Memorising the name and the symbol of each of the first 20 Elements, on the Periodic Table, as well as Iron (Fe), Copper (Cu), Zinc (Zn)" [36] (p. 63). The periodic table is identified as a teaching resource. In this instance, the researcher classified this topic and relevant content and concepts and resources as following the discipline-centered ideology (Table 3). This is because the knowledge (i.e., elements of the periodic table) already exists, which students must memorize. Memorizing is classified as rote learning, which is typical of a discipline-centered ideology. This classification approach was used to classify other parts of the curriculum, as shown in Table 3. Results showed that all four curriculum ideologies are reflected in content knowledge.

\section{Discussion}

The significance of curriculum ideologies in science continues to be an important research focus area as it provides a clearer lens through which curriculum and instructional design can be understood. On this basis, researchers [37] have explored the representation of the nature of sciences in science textbooks within the context of curriculum ideologies. Likewise, Molapo and Pillay [38] have suggested that curriculum implementation could be hampered by the politicization of education, which could be understood as adopting 
curriculum ideologies that do not support the advancement of a discipline or student development.

The issues raised in literature may require a shift in curriculum ideologies informing school science to support an integrated curriculum, which supports learner development, advancement of disciplines, empowerment of communities, and provision of relevant social services skills. On this basis, the present research explored the extent to which a school science subject could effectively integrate different curriculum ideologies.

The present research's significant finding is that based on the Natural Sciences case study, school science subjects may integrate different curriculum ideologies into a mélange of curriculum ideologies. In the current research, this integration of different curriculum ideologies was found in that all four curriculum ideologies-namely, the student-centered, service-centered, discipline-centered, and citizenship-centered ideologies-were represented. This is probably because Natural Sciences integrates content knowledge from various science disciplines as a school science subject. The integration of multiple ideologies in a single school subject is in line with the views of Humphreys et al. [3], Lake [4], Magoma [39], and Shoemaker [5], who have argued that in an integrated curriculum, students should be exposed to a broad spectrum of knowledge and worldviews. Fraser [2] also supports integrating multiple curriculum ideologies, suggesting that curricula should satisfy the needs of science, students, and society. Integrated curriculum ideologies further support Chisholm's [7] view that curricula are used to meet all stakeholders' socio-political needs in a' curriculum as a policy' perspective.

While integrating curriculum ideologies is recommended in the literature, it is not well documented how this should be carried out. For example, to what extent should each ideology be presented, and what aspects of the curriculum? While there is no blueprint to respond to this question, the present research has shown that in Natural Sciences, the discipline-centered ideology was most reflected in the purpose of the subject and the nature of content knowledge. The student-centered ideology was most reflected in the instructional process and the roles of teachers and students. These findings suggest that curriculum designers in Natural Sciences accept the disciplines' autonomy by ensuring that knowledge acquired in the subject is scientifically authentic. However, they also accept the need to ensure that the student's personal needs are met. These could include preferred learning styles and unique requirements related to cognitive, affective, and psychomotor development. The service-centered ideology was dominant in the assessment. It was the second most dominant ideology in the nature of knowledge, instructional process, and the teachers' and students' roles. This suggests that the curriculum intends to prepare students for a future where they could use specific skills and knowledge to render services such as in a workplace.

While the integration of curriculum ideologies represents "considerable face validity and commonsense appeal", several concerns cannot be ignored [40] (p. 263). For example, previous research has reported that teachers may have specific preferred ideologies, which do not support curriculum ideologies reflected in a curriculum $[16,41]$. Consequently, if teachers are not prepared to adopt integrated curriculum ideologies, basic instructional design and teaching methodologies could lead to "trivialisation of concepts" and "fail to enhance student understanding of important" scientific ideas, including the nature of science [40]. Meier et al. [42] (p. 439) cautioned that there had not been enough research documenting "evidence that integration will produce the desired effects... Without evidence that integration will produce improved student performance in mathematics and science, little change can be expected".

Therefore, based on the findings of the current research, the current researcher cautiously argues that school science subjects could be used to support social justice, including social, economic empowerment, without radically dismantling educational and scientific norms, structures, and policies and practices [6]. It is apparent that social justice promotion could be achieved through the principles of student-centered and service-centered ideologies, while those of discipline-centered ideology would ensure that functioning 
educational norms, structures, and policies and practices remain in place. However, in line with Mnguni [11,25], the current researcher argues that the minimal focus on the citizenship-centered ideology may hinder the intention to promote social reconstruction related to racial and economic redress as envisaged in the South Africa context. This is because, through a citizenship-centered ideology, students could learn knowledge and develop skills required to identify social ills and generate effective strategies for social reconstruction [28]. Consequently, the poor representation of the citizenship-centered ideology may harm the social emancipation ideals [6].

\section{Conclusions}

The current research has established that it is generally possible to integrate different curriculum ideologies in a school science subject to support the global democratic value systems. However, further research is required to determine the extent to which different curriculum ideologies can be integrated without compromising the authentic nature of science and effective learning. As shown in the current research, there is a possibility that school science subjects may not meet the curriculum imperatives related to democratic values due to the nature and manner in which curriculum ideologies are integrated. Furthermore, it is likely that teachers will find it challenging to implement the curriculum where they have also to adopt teaching methods that satisfy all four curriculum ideologies. Consequently, teachers may not know which curriculum ideology principles should be adopted within their immediate teaching environment and between different teaching environments. As such, students in different schools may be taught according to different sets of curriculum ideology principles. This lack of consistency may ultimately hinder the attainment of the curriculum objectives. Therefore, the researchers recommend further research to determine the extent to which teachers can integrate multiple curriculum ideologies in their teaching. Such research could further enhance our understanding of curriculum and instructional design within the context of democratic principles.

Funding: The research was funded by the South African National Research Foundation (NRF) (GUN 118115).

Institutional Review Board Statement: The study was conducted according to the guidelines of the Declaration of Helsinki, and approved by the Ethics Committee of the College of Education, University of South Africa (reference number 2018/11/14/90291786/01/MC).

Informed Consent Statement: Not applicable.

Data Availability Statement: Not applicable.

Conflicts of Interest: The author declares no conflict of interest.

\section{References}

1. Drake, S.M.; Reid, J.L. Integrated Curriculum as an Effective Way to Teach 21st-Century Capabilities. Asia Pac. J. Educ. Res. 2018, 1, 31-50. [CrossRef]

2. Fraser, W.J.; Loubser, C.P.; van Rooy, M.P. Didactics for the Undergraduate Student, 2nd ed.; Heinemann Publishers: Durban, South Africa, 1993.

3. Humphreys, A.; Post, T.; Ellis, A. Interdisciplinary Methods: A Thematic Approach; Goodyear Publishing Company: Santa Monica, CA, USA, 1981.

4. Lake, K. Integrated Curriculum: School Improvement Research Series, Close Up \#16. Office of Educational Research and Improvement. 1994. Available online: http:/ / www.nwrel.org/scpd/sirs/8/c016.html (accessed on 14 June 2018).

5. Shoemaker, B.J.E. Integrative Education: A Curriculum for the Twenty-First Century. OSSC Bull. 1989, 33, 57.

6. Badat, S.; Sayed, Y. Post-1994 South African Education: The Challenge of Social Justice. Ann. Am. Acad. Political Soc. Sci. 2014, 652, 127-148. [CrossRef]

7. Chisholm, L. The Making of South Africa's National Curriculum Statement. J. Curric. Stud. 2005, 37, 193-208. [CrossRef]

8. Waghid, Y. Knowledge Production and Higher Education Transformation in South Africa: Towards Reflexivity in University Teaching, Research, and Community Service. High. Educ. 2002, 43, 457-488. [CrossRef]

9. Waghid, Y. Action as an Educational Virtue: Toward a Different Understanding of Democratic Citizenship Education. Educ. Theory 2005, 55, 323-342. 
10. Bantwini, B.D. How Teachers Perceive the New Curriculum Reform: Lessons from a School District in the Eastern Cape Province, South Africa. Int. J. Educ. Dev. 2010, 30, 83-90. [CrossRef]

11. Mnguni, L. Citizenship Education and the Curriculum Ideologies of Natural Sciences and Life Sciences Curricula in South Africa. Curric. Perspect. 2018, 38, 97-106. [CrossRef]

12. Hoeg, D.G.; Bencze, J.L. Values Underpinning STEM Education in the USA: An Analysis of the next Generation Science Standards: Values Underpinning Stem Education. Sci. Educ. 2017, 101, 278-301. [CrossRef]

13. Pietarinen, J.; Pyhältö, K.; Soini, T. Large-Scale Curriculum Reform in Finland-Exploring the Interrelation between Implementation Strategy, the Function of the Reform, and Curriculum Coherence. Curric. J. 2017, 28, 22-40. [CrossRef]

14. Porter, R.E.; Fusarelli, L.D.; Fusarelli, B.C. Implementing the Common Core: How Educators Interpret Curriculum Reform. Educ. Policy 2015, 29, 111-139. [CrossRef]

15. Bulut, M. Curriculum Reform in Turkey: A Case of Primary School Mathematics Curriculum. Eurasia J. Math. Sci. Technol. Educ. 2007, 3, 203-212. [CrossRef]

16. Mnguni, L.; El Islami, R.A.Z.; Hebe, H.; Sari, I.J.; Nestiadi, A. A Comparison of the South African and Indonesian Teachers Preferred Curriculum Ideology for School Science. Curric. Perspect. 2020, 40, 3-13. [CrossRef]

17. Dowden, T. Relevant, Challenging, Integrative, and Exploratory Curriculum Design: Perspectives from Theory and Practice for Middle-Level Schooling in Australia. Aust. Educ. Res. 2007, 34, 51-71. [CrossRef]

18. Lam, C.C.; Alviar-Martin, T.; Adler, S.A.; Sim, J.B.Y. Curriculum Integration in Singapore: Teachers' Perspectives and Practice. Teach. Teach. Educ. 2013, 31, 23-34. [CrossRef]

19. Fullan, M. The New Meaning of Education Change, 4th ed.; Teachers College Press: New York, NY, USA, 2007.

20. Gopinathan, S.; Deng, Z. Fostering School-Based Curriculum Development in the Context of New Educational Initiatives in Singapore. Plan. Chang. 2006, 37, 93-110.

21. Marsh, C.J.; Willis, G. Curriculum: Alternative Approaches, 4th ed.; Pearson: Hoboken, NJ, USA, 2007.

22. Beane, J.A. Curriculum Integration: Designing the Core of Democratic Education; Teachers College Press: New York, NY, USA, 1997.

23. Posner, G.J. Analyzing the Curriculum; McGraw-Hill Humanities Social: New York, NY, USA, 1995.

24. Ornstein, A.C.; Hunkins, F.P. Curriculum: Foundations, Principles, and Issues, Global Edition, 7th ed.; Pearson Education: London, UK, 2017.

25. Mnguni, L. The Curriculum Ideology of the South African Secondary School Biology. S. Afr. J. Educ. 2013, 33, 1-11. [CrossRef]

26. Cotti, R.; Schiro, M. Connecting Teacher Beliefs to the Use of Children's Literature in the Teaching of Mathematics. J. Math. Teach. Educ. 2004, 7, 329-356. [CrossRef]

27. Ravitch, D. The Great School Wars: A History of the New York City Public Schools; JHU Press: Baltimore, MD, USA, 2000.

28. Schiro, M.S. Curriculum Theory: Conflicting Visions and Enduring Concerns; Sage: Thousand Oaks, CA, USA, 2008.

29. Kliebard, H.M. The Struggle for the American Curriculum, 1893-1958, 4th ed.; Routledge: Oxfordshire, UK, 2011.

30. McNeil, J.D. Curriculum: A Comprehensive Introduction; Little-Brown: Boston, MA, USA, 1977.

31. Schubert, W.H. Perspectives on Four Curriculum Traditions. Educ. Horiz. 1996, 74, 169-176.

32. Krauss, S.E. Research Paradigms and Meaning-Making: A Primer. Qual. Rep. 2005, 10, 758-770.

33. Downe-Wamboldt, B. Content Analysis: Method, Applications, and Issues. Health Care Women Int. 1992, 13, 313-321. [CrossRef]

34. Frey, B.B. The SAGE Encyclopedia of Educational Research, Measurement, and Evaluation; SAGE Publications, Inc.: Thousand Oaks, CA, USA, 2018.

35. Bowen, G.A. Document Analysis as a Qualitative Research Method. Qual. Res. J. 2009, 9, 27-40. [CrossRef]

36. Department of Basic Education; Natural Sciences and Technology. Curriculum and Assessment Policy Statement Grade 7-9; Department of Basic Education: Pretoria, South Africa, 2011. Available online: https:/ /www.education.gov.za/LinkClick.aspx? fileticket=IzbFrpzoQ44= (accessed on 14 March 2014).

37. Masilela, T.E.; Ramaila, S. The Representation of the Nature of Science in South African Grade 12 Life Sciences Textbooks; University of Johannesburg (South Africa): Johannesburg, South Africa, 2019; pp. 56-69.

38. Molapo, M.R.; Pillay, V. Politicising Curriculum Implementation: The Case of Primary Schools. S. Afr. J. Educ. 2018, 38, 1-9. [CrossRef]

39. Magoma, C.M. The Shift and Emphasis towards Curriculum Integration: Meaning and Rationale. Afr. Educ. Res. J. 2016, 4, 25-30.

40. Mason, T.C. Integrated Curricula: Potential and Problems. J. Teach. Educ. 1996, 47, 263-270. [CrossRef]

41. Mnguni, L. The Curriculum Ideology Recommended by Novice Teachers for Life Sciences in South Africa. EURASIA J. Math. Sci. Technol. Educ. 2018, 14, 3099-3108. [CrossRef]

42. Meier, S.L.; Nicol, M.; Cobbs, G. Potential Benefits and Barriers to Integration. Sch. Sci. Math. 1998, 98, 438-447. [CrossRef] 